University of Nebraska - Lincoln

DigitalCommons@University of Nebraska - Lincoln

1984

\title{
ARMORED MUD BALLS AND FRIABLE SAND MEGACLASTS FROM A COMPLEX EARLY PLEISTOCENE ALLUVIAL FILL, SOUTHWESTERN MORRILL COUNTY, NEBRASKA
}

R. F. Diffendal

University of Nebraska-Lincoln, rdiffendal1@unl.edu

Follow this and additional works at: https://digitalcommons.unl.edu/diffendal

Part of the Geology Commons

Diffendal, R. F., "ARMORED MUD BALLS AND FRIABLE SAND MEGACLASTS FROM A COMPLEX EARLY PLEISTOCENE ALLUVIAL FILL, SOUTHWESTERN MORRILL COUNTY, NEBRASKA" (1984). Robert $F$. Diffendal, Jr., Publications. 1.

https://digitalcommons.unl.edu/diffendal/1

This Article is brought to you for free and open access by the Natural Resources, School of at DigitalCommons@University of Nebraska - Lincoln. It has been accepted for inclusion in Robert F. Diffendal, Jr., Publications by an authorized administrator of DigitalCommons@University of Nebraska - Lincoln. 


\title{
GEOLOGICAL NOTES
}

\author{
ARMORED MUD BALLS AND FRIABLE SAND MEGACLASTS \\ FROM A COMPLEX EARLY PLEISTOCENE ALLUVIAL FILL, \\ SOUTHWESTERN MORRILL COUNTY, NEBRASKA ${ }^{1}$
}

\author{
R. F. DIFFENDAL \\ Conservation and Survey Division, IANR, University of Nebraska-Lincoln, Lincoln, NE 68588-0517
}

\begin{abstract}
Armored mud balls and friable sand megaclasts occur in exposures of a complex Early Pleistocene sand and gravel alluvial fill which caps a strath terrace in southwestern Morrill County, Nebraska. The mud balls are limited to a tributary arroyo. The sand megaclasts occur in sediments deposited along a trunk stream. It is possible that the sand megaclasts were transported to the site in a frozen condition.
\end{abstract}

\section{INTRODUCTION}

Early Pleistocene alluvial sand and gravel cap a strath terrace remnant in southwestern Morrill County, Nebraska. These deposits, which are exposed in a gravel pit on the Wright Ranch (fig. 1), were first studied by the author in 1980 . Since that time the pit has been enlarged to the south by about $5 \mathrm{~m}$, and the new working face contains types of clasts that did not occur in the original face. The most unusual of these clasts are armored mud balls and friable sand boulders much larger than the surrounding matrix (megaclasts). The purposes of this note are to illustrate and describe these features and to suggest some ideas about the nature of the streams that carried them.

\section{LOCATION AND DESCRIPTION OF FEATURES}

The Wright Ranch Gravel Pit is developed on the highest and oldest strath terrace remnant preserved in Pumpkin Creek Valley. The sediments and fossils found in the pit have been described previously by Diffendal and Corner (1983) and Corner and Diffendal (1983).

The working face presently exposed is about $20 \mathrm{~m}$ long and about 4 to $4.5 \mathrm{~m}$ high (fig. 2). The basal $2 \mathrm{~m}$ thick part of the sequence

\footnotetext{
${ }^{1}$ Manuscript received December 27, 1983; revised February 2, 1984.

[Journal of Geology, 1984, vol. 92, p. 325-330] (C) 1984 by The University of Chicago. All rights reserved.

0022-1376/84/9203-005\$1.00
}

consists of alternating discontinuous layers of very fine to medium sand interbedded with sand and gravel, including clasts up to cobble size. Above these deposits is a mass of sand and gravel deposited in a complex cut and fill succession about $2 \mathrm{~m}$ thick. A dark-colored, burrowed soil and alluvium complex about 0.5 to $1 \mathrm{~m}$ thick caps the sequence.

Armored mud balls occur in an Early Pleistocene channel fill directly beneath one part of the soil and alluvium complex (fig. 3). The channel fill is about $3 \mathrm{~m}$ wide and about $1 \mathrm{~m}$ thick. The sediments filling the channel consist principally of masses of friable very fine to medium sand and volcaniclastic sandstone and siltstone gravels derived from Oligocene and Miocene sedimentary rocks cropping out to the south along the escarpment forming the border of the Cheyenne Tablelands. Granite and anorthosite gravels derived from the Laramie Range to the west in southeastern Wyoming are important lesser components. These sediments fill an Early Pleistocene arroyo that drained from the south. Similar ancient tributary fills have been reported on previously in the area by Diffendal and Corner (1983).

Four armored mud balls are exposed in the fill. The three largest mud balls occur at or near the base of the fill, and a smaller mud ball occurs about $25 \mathrm{~cm}$ below the top of the fill. The mud balls are well rounded and appear to be nearly spherical. The three largest ones have minimum diameters of 22 to $26 \mathrm{~cm}$ and are armored with both the locally and distantly derived gravels found in the remain- 


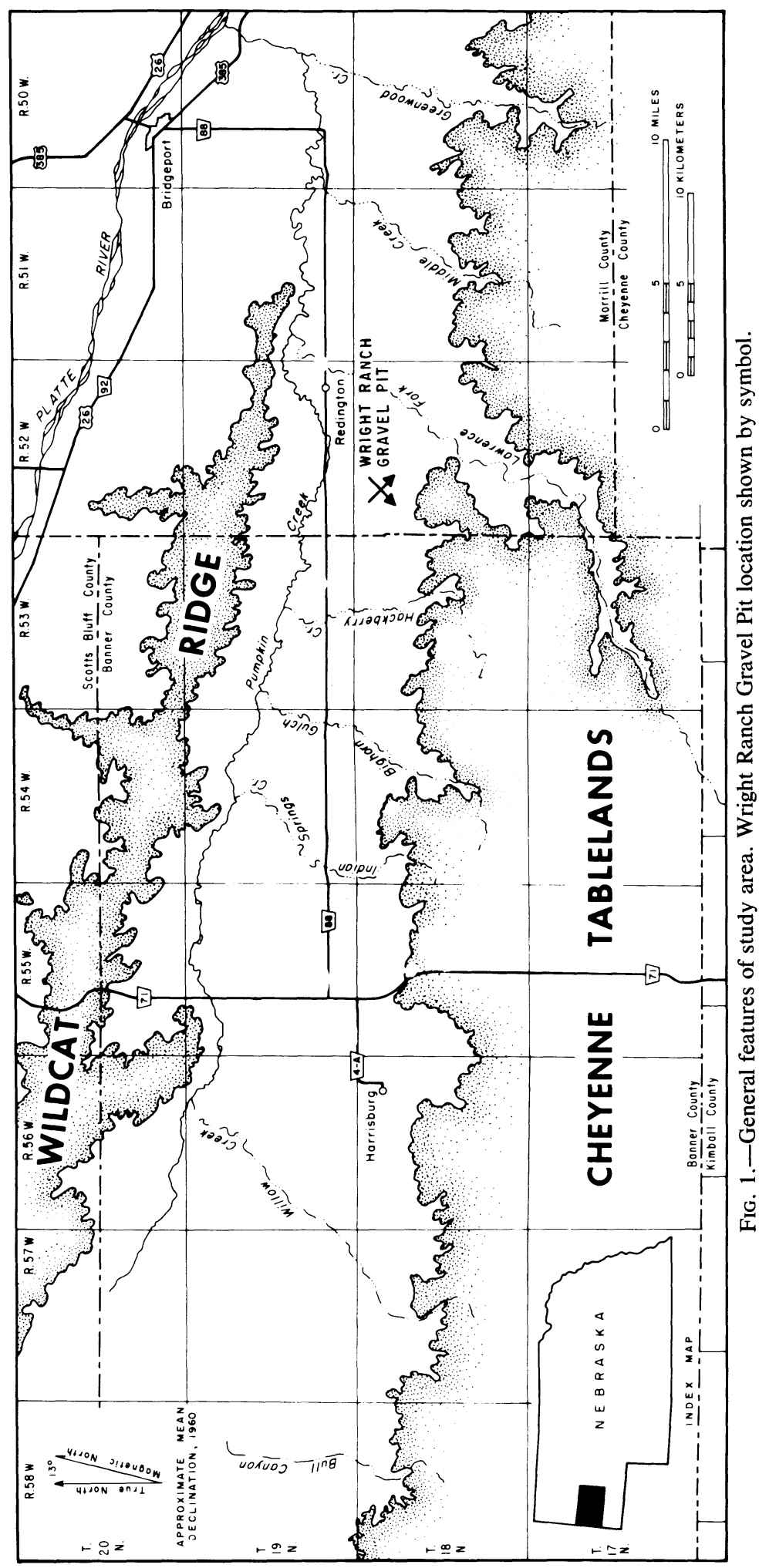




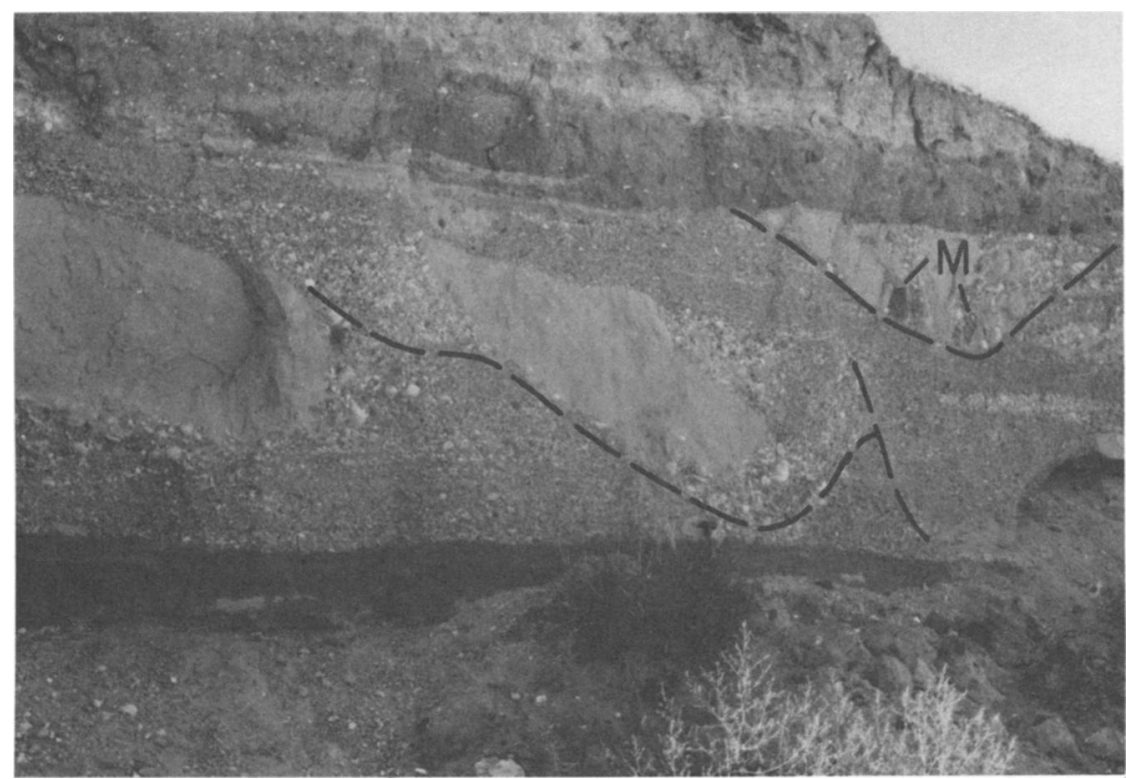

Fig. 2.-Part of working face of gravel pit showing complex fill, and soil and alluvium complex. Dashed lines indicate bases of fills. " $M$ " designates armored mud balls.

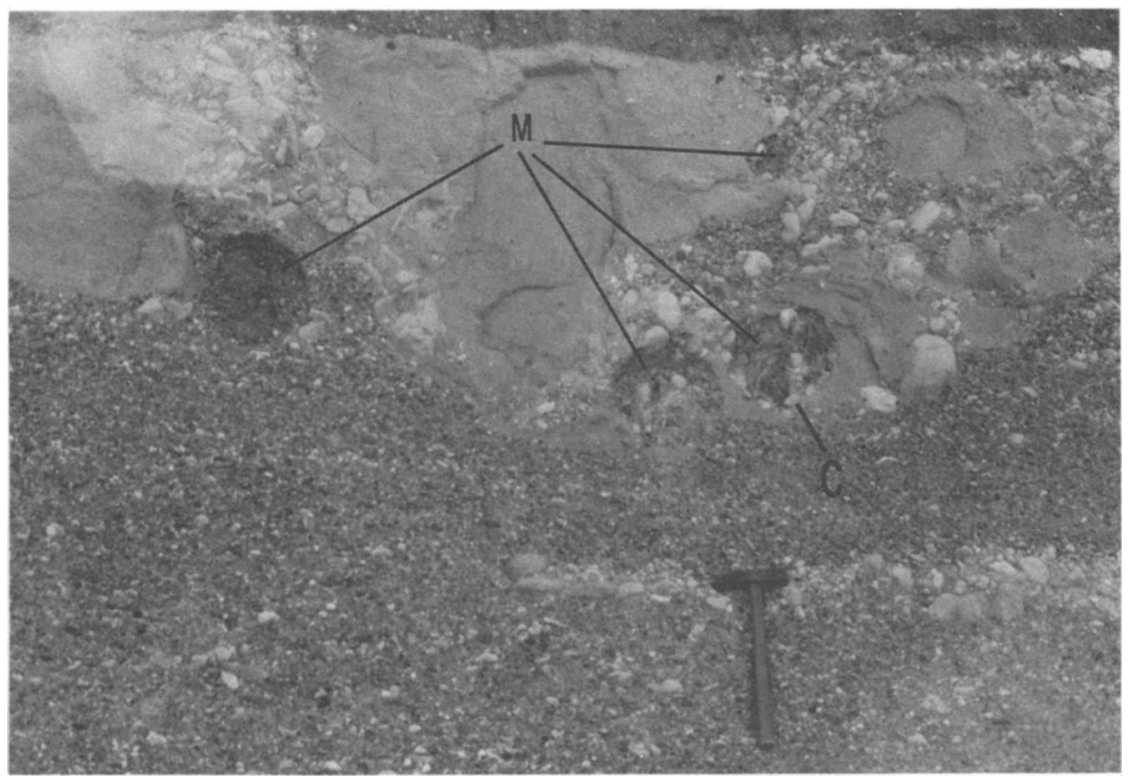

FIG. 3.-Predominantly locally derived alluvium filling tributary arroyo. " $M$ " indicates armored mud balls. Armored mud ball " $\mathrm{C}$ " about $26 \mathrm{~cm}$ in intermediate diameter has basal crack filled with coarser sediment. Hammer is $40.6 \mathrm{~cm}$ long. 


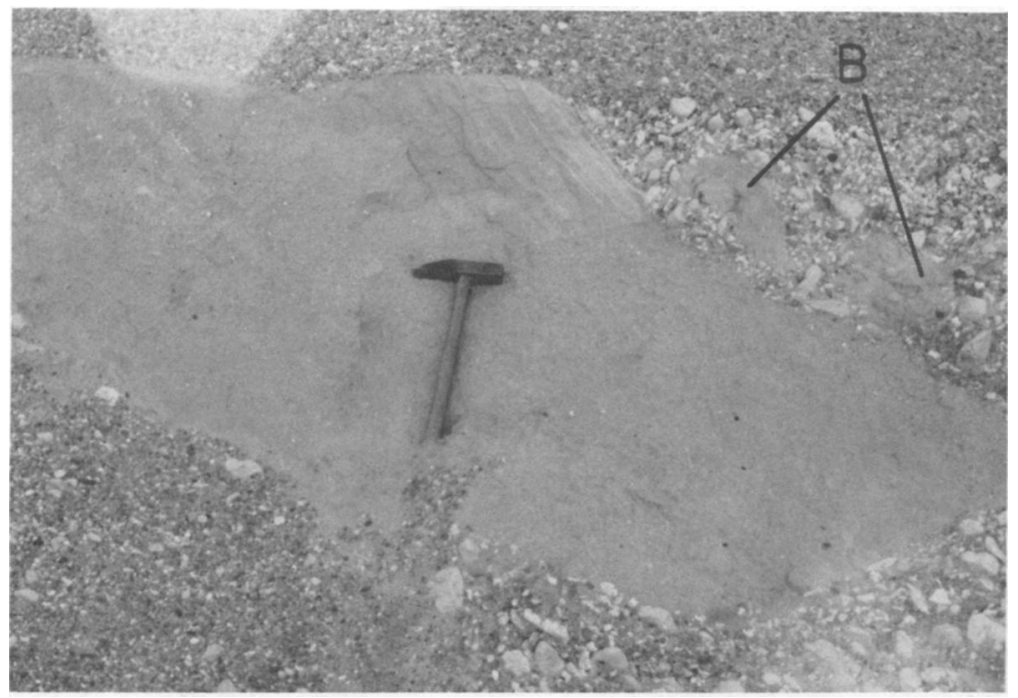

FIG. 4.-Friable sand megaclast with steeply dipping laminations. Megaclast is surrounded by coarser sand and gravel including two sand blocks, " $\mathrm{B}$ ". Hammer is $40.6 \mathrm{~cm}$ long.

der of the fill. The mud forming the main part of the mud balls is moderate brown $\left(5 \mathrm{YR}^{4} / 4\right.$ to $\left.5 \mathrm{YR}^{3} / 4\right)$. One of the mud balls was cracked at some stage in its formation and coarser sediment has filled the crack (fig. 3). Similar filled cracks have been reported in some Jurassic armored mud balls from Massachusetts by Little (1982).

The remainder of the complex fill generally has far more anorthosite and granitic gravel than does the deposit containing the armored mud balls. One of the fills in this complex includes a mass of friable very fine to medium sand with some thin parallel laminations (fig. 4). These laminations dip to the westsouthwest at about $55^{\circ}$, considerably above the angle of repose of sandy sediments.

Massive friable sand clasts containing broken rhizoconcretions occur to the west in the exposure. Some of these clasts are rounded to well rounded (fig. 5) and have diameters of at least $50 \mathrm{~cm}$. These megaclasts are over an order of magnitude larger than the largest distantly derived clasts surrounding them.

\section{INTERPRETATIONS}

General discussions concerning occurrence, significance, and mode of formation of armored mud balls are given by Pettijohn (1975, p. 478-479) and Picard and High (1973, p. 49-51). Bell (1940) prepared a detailed account including experimental results on de- velopment of mud balls. Of particular importance is the inverse relationship reported by Bell (1940, p. 13) between the diameter of an armored mud ball and the maximum velocity of the stream transporting the ball. Using Bell's calculations, the armored mud balls in the arroyo fill exposed in the Wright Ranch Gravel Pit were transported to the site by water flowing with a velocity ranging between 1.5 and $2.4 \mathrm{~m} / \mathrm{sec}$, and probably close to 1.8 $\mathrm{m} / \mathrm{sec}$.

Much of the remainder of the complex fill is not a locally derived deposit but, instead, is part of the main fill of ancestral Pumpkin Creek. The maximum intermediate diameter of a distantly derived anorthositic gravel clast in this deposit reported by Diffendal and Corner $(1983$, p. 727$)$ is $13.2 \mathrm{~cm}$. Using the plot of diameter versus mean speed of flow supplied by Friedman and Sanders (1978, p. 107), the minimum mean speed of flow needed to transport such particles in water would be between 1 and $2 \mathrm{~m} / \mathrm{sec}$.

While the origin of armored mud balls is easy to explain, the presence of rounded friable sand megaclasts in the deposit is difficult. The rounding suggests transport, but the material is so loose that it could not have been moved by water in its present physical condition without falling apart rapidly. Since it was moved, and since the sand does not occur in outcrop anywhere on the 


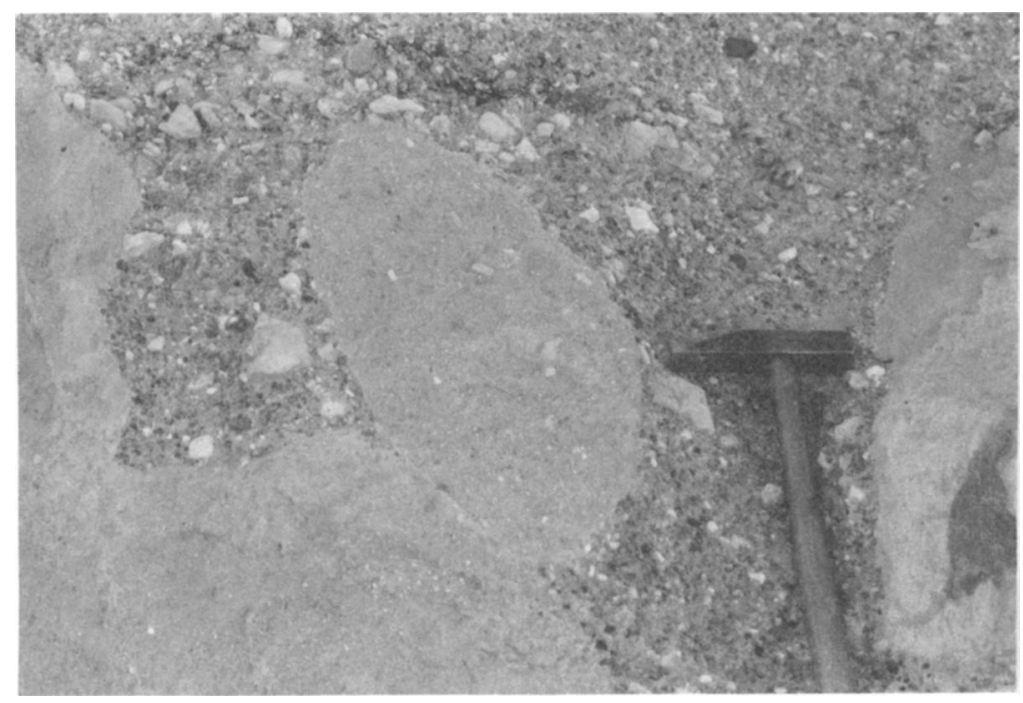

Fig. 5.-Massive friable sand boulder surrounded by other sand masses and coarser sediment. Hammer is $40.6 \mathrm{~cm}$ long.

strath terrace remnant, the megaclasts probably were transported at least more than a few tens of meters from their sources.

There are at least two possible ways to have moved what are now large masses of loose sand without disaggregation. Either the masses could have been cemented originally and the cement has subsequently been leached away by ground water, or the sand could have been held together by interstitial ice and the ice later melted leaving the intact megaclasts behind. The first possibility is unlikely because unleached blocks of locally derived sandstone occur throughout the complex fill, but selective leaching could have occurred. The second possibility, suggested to the author originally by W. J. Wayne (personal comm. 1983), is more likely. Barbour (1914, p. 808-809) suggested a similar origin for unusual masses of sediment in glacial tills in eastern Nebraska, but the author has not been able to find any descriptions in coldclimate literature of clasts forming in such a way today.

Mears (1981) has reported Late Pleistocene and possibly older periglacial wedges in the basins of Wyoming, but no cold-climate features seem to have been noted previously from western Nebraska. If the sand megaclasts described above were formed while in an originally frozen state, they would be evidence of cold climate in the panhandle during the Early Pleistocene. Anyone studying the Quaternary deposits of western Nebraska in the future should look for such evidence, particularly in areas where alluvium is preserved, so that the paleoclimatic history of the area can be refined further.

\section{CONCLUSIONS}

1. Armored mud balls occur in an Early Pleistocene arroyo fill in western Nebraska. They probably formed under environmental conditions similar to those found along arroyos in parts of western Nebraska where mud balls are forming today.

2. Friable sand megaclasts occur in the sand and gravel fill and may have been transported originally to the site in a frozen condition.

3. Any freshly cut working face in Cenozoic sand and gravel deposits in western $\mathrm{Ne}$ braska and adjacent areas should be examined for similar features.

ACKNOWLEDgments. - W. J. Wayne visited the site with the author and offered helpful suggestions on the origins of features observed there. D. Loope, W. J. Wayne, M. R. Voorhies, R. Burchett, K. Messenger, and D. Eversoll offered suggestions for improvement of the manuscript. 


\section{REFERENCES CITED}

Barbour, E. H., 1914, A phenomenon of the Kansan drift in Nebraska: Jour. Geology, v. 22, p. 807-810.

BeLl, H. S., 1940, Armored mud balls: their origin, properties, and role in sedimentation: Jour. Geology, v. 48, p. 1-31.

Corner, R. G., and DifFendal, R. F., JR., 1983, An Irvingtonian fauna from the oldest Quaternary alluvium in eastern Pumpkin Creek Valley, Morrill and Banner counties, Nebraska: Univ. of Wyoming, Contrib. to Geology, v. 22, p. 39-43.

DifFendal, R. F., JR., and Corner, R. G., 1983, Asymmetrical distribution of Quaternary alluvial fills, Pumpkin Creek drainage basin, western Nebraska: Geol. Soc. America Bull., v. 94, p. 720729.
Friedman, G. M., and Sanders, J. E., 1978, Principles of Sedimentology: New York, Wiley, 792 p. LiTtLE, R. D., 1982, Lithified armored mud balls of the Lower Jurassic Turners Falls Sandstone, north-central Massachusetts: Jour. Geology, v. 90, p. 203-207.

Mears, B., JR., 1981, Periglacial wedges and the Late Pleistocene environment of Wyoming's intermontane basins: Quaternary Res., v. 15, p. 171-198.

Pettijohn, F. J., 1975, Sedimentary Rocks (3d ed.): New York, Harper and Brothers, $628 \mathrm{p}$.

Picard, M. D., and High, L. R., JR., 1973, Sedimentary Structures of Ephemeral Streams: Amsterdam, Elsevier, 223 p. 